\title{
Plasmid and Chromosomal Determination of Agrobacterium Adherence Specificity
}

\author{
By MARIAMNE H. WHATLEY,* JEAN B. MARGOT,* JEF SCHELL, $\dagger$ \\ BARBARA B. LIPPINCOTT* AND JAMES A. LIPPINCOTT* \\ * Department of Biological Sciences, Northwestern University, Evanston, \\ Illinois 60201, U.S.A. \\ $\uparrow$ Laboratorium voor Genetica, Rijksuniversiteit Gent, B-9000 Gent, Belgium
}

(Received 16 January 1978; revised 3 April 1978)

INTRODUCTION

To initiate tumours Agrobacterium tumefaciens must adhere to a wound site via a process which requires considerable specificity on the part of the bacterium (Lippincott \& Lippincott, 1969; Whatley et al., 1976). Because this site binding ability and the presence of a large plasmid (Zaenen et al., 1974) are both essential for tumourigenicity, it was of interest to determine if site binding ability was a plasmid-borne trait. Whatley et al. (1976) showed that lipopolysaccharide (LPS) of the outer membrane of the Agrobacterium cell envelope is the bacterial adherence component. Two avirulent strains of Agrobacterium derived from virulent strains and reported to be plasmid-free were found to retain site binding ability (Whatley et al., 1976). It was proposed, therefore, that chromosomal DNA determined the specificity of LPS essential for adherence (Whatley et al., 1976).

Van Larebeke et al. (1975) reported that introduction of a virulence plasmid into Agrobacterium radiobacter strain s1005 converted this strain to a tumourigenic state. However, whole cells and LPS of strain s1005 lack the ability to adhere to tumour initiation sites (Lippincott \& Lippincott, 1969; Whatley et al., 1976). Thus, either the strains of s1005 tested in the two laboratories differed in their site binding ability, or the presence of the plasmid in 1005 must affect LPS structure. To resolve these possibilities we determined the localization of genes governing adherence by testing non-site binding strains to which a virulence plasmid was added and additional site binding strains after curing of all plasmids.

\section{METHODS}

Characteristics of $A$. tumefaciens tumourigenic strains $\mathbf{B} 6$ and 181 and non-tumourigenic $A$. radiobacter strains S1005, TR1 and ATCC 6467 have been described (Lippincott \& Lippincott, 1969). Strain NT1, obtained from E. Nester, University of Washington, Seattle, U.S.A., was derived from A. tumefaciens strain c58 by growth at $37^{\circ} \mathrm{C}$ and lacks only the large plasmid for virulence (Watson et al., 1975). Plasmid-cured strains C58C9 (virulent parental strain $\mathrm{C58}$ ) and $\mathrm{ACH} 5 \mathrm{C} 3$ (virulent parental strain $\mathrm{ACH} 5$ ) were also obtained by this method. Strain B91Q5 is a plasmid-cured isolate of virulent strain B91 selected by its failure to utilize octopine (Petit \& Tourneur, 1972). Agrobacterium radiobacter strain K84, source of agrocin 84 (Kerr \& Htay, 1974) was obtained from A. Kerr, University of Adelaide, Australia. Strain B6s3 is a single colony isolate from an ultraviolet-irradiated, mitomycin C-treated в6 culture (Zaenen et al., 1974).

Tumourigenic strain s1005(pTiK14) was obtained by in planta transfer of the plasmid of $A$. tumefaciens strain $\mathrm{k} 14$ to $A$. radiobacter strain s1005 (Van Larebeke $e t$ al., 1975). The plasmid from strain B6s3 was transferred to non-site binding $A$. radiobacter strains S1005, TR1 and ATCC 6467 from three donor strains, B6s3, c58c9(pTiB6S3) and LBA52 (an auxotrophic mutant of $\mathrm{B} 6 \mathrm{~s} 3$ ), following in vitro conjugation as described by Genetello et al. (1977). Chromosomal genes have not been observed to transfer in this process. Plasmid content was determined by the methods described by Zaenen et al. (1974) and Currier \& Nester (1976a).

Washed bacteria were lyophilized and LPS was obtained by treating the cells with $45 \%(\mathrm{w} / \mathrm{v})$ phenol in water as described by Westphal \& Jann (1965). LPS was purified by two ultracentrifugations or by chromatography on columns of Sepharose 2B, dialysed and lyophilized as described by Whatley et al. (1976). The 
dry LPS was weighed and dissolved in distilled water by heating at $55^{\circ} \mathrm{C}$ for 5 min for use in infectivity assays.

Viable or heat-killed bacteria or their LPS were mixed with viable virulent strain B6 and applied with carborundum wounding to 7-d-old primary pinto bean leaves (Lippincott \& Heberlein, 1965). Samples and controls were each inoculated on 16 to 20 leaves and the number of tumours initiated was counted $7 \mathrm{~d}$ later. Data are reported as a percentage of the number of control tumours, values of $80 \%$ or less providing evidence for the ability of the test materials to compete with strain $\mathrm{B} 6$ for attachment sites. The controls were portions of the same culture of virulent bacteria used in the experimental samples inoculated at the same concentrations.

Bacterial sensitivity to agrocin 84 was used to select for cured non-infectious derivatives of strains s1005(pTiK14) and 181 (Engler et al., 1975; Watson et al., 1975).

\section{RESULTS AND DISCUSSION}

The plasmid from strain B6s3 was transferred to three strains of $A$. radiobacter, 6467, TR1 and $\mathbf{s} 1005$, previously found to be non-site binding (Lippincott \& Lippincott, 1969). Rifampicin-resistant colonies with a plasmid were selected by their capacity to grow on minimal medium with octopine as sole nitrogen and carbon source, a character determined by the strain B6s3 plasmid (Genetello et al., 1977). Three different donor strains, each carrying the $\mathrm{B} 6 \mathrm{~s} 3$ plasmid, were used to supply the plasmid to the $A$. radiobacter strains. All transconjugants were tumourigenic, suggesting plasmid gain carried site binding ability similar to that observed in transconjugant strain s1005(pTiK14). When whole cells and LPS from these transconjugant strains were tested for their effect on tumour initiation, they proved inhibitory as predicted by their virulence (Table 1).

The virulent strain $\mathrm{s} 1005$ (pTiK14), formed by introduction of the strain K14 plasmid into the avirulent non-site binding strain s1005, induced tumours on pinto bean leaves and both whole cells and LPS derived from this strain inhibited tumour formation by strain $\mathrm{B} 6$ (Table 1). The plasmid from strain $\mathrm{k} 14$ also carries genes that confer nopaline utilization and sensitivity to agrocin 84 on strain $\mathrm{s} 1005$ (pTiK14). Three agrocin-resistant derivatives of strain s1005(pTiK14) were selected and all were found to be avirulent and unable to utilize nopaline. Both whole cells and LPS from these plasmid-cured strains were noninhibitory when tested in tumour initiation assays, and no plasmid DNA was detected in them by direct analysis.

Agrobacterium tumefaciens strain 181 is tumourigenic, sensitive to agrocin 84 and contains two plasmids with molecular weights of $114 \times 10^{6}$ and $158 \times 10^{6}$ (Currier \& Nester, 1976b). Two agrocin 84-resistant isolates of this strain were selected and found to be avirulent (Table 1). However, whole cells of these strains and their LPS were still inhibitory in infectivity tests. These strains lack one of the two strain 181 plasmids and do not utilize nopaline, a trait present in the parental strain (Lippincott et al., 1973) and determined by the virulence plasmid (Watson et al., 1975; Bomhoff et al., 1976).

These data show that plasmid transfer conveying virulence to non-tumourigenic non-site binding strains of Agrobacterium also conveys site binding ability in the case of two plasmids (pTiK14 and pTiB6S3) in three strains of bacteria (s1005, TR1, 6467). Plasmid-cured variants obtained from one of these strains, $\mathrm{s} 1005$ (pTiK14), showed loss of site binding ability as well as loss of virulence and nopaline utilization. Thus, in addition to such traits as virulence, octopine or nopaline utilization (Watson et al., 1975; Bomhoff et al., 1976), agrocin 84 sensitivity (Engler et al., 1975; Watson et al., 1975; Kerr \& Roberts, 1976) and exclusion of phage AP1 (Van Larebeke et al., 1975), virulence plasmids may also contain information governing one or more features of LPS structure.

Many avirulent agrobacteria, however, show site binding ability and LPS from these strains is inhibitory (Lippincott \& Lippincott, 1969; Whatley et al., 1976). The plasmid content of most of these strains is unknown. Agrocin 84-resistant strains derived from virulent strain 181 have lost a plasmid essential for virulence and nopaline utilization but retain site binding ability. Plasmid-free strain NT1 retained site binding ability in the absence 


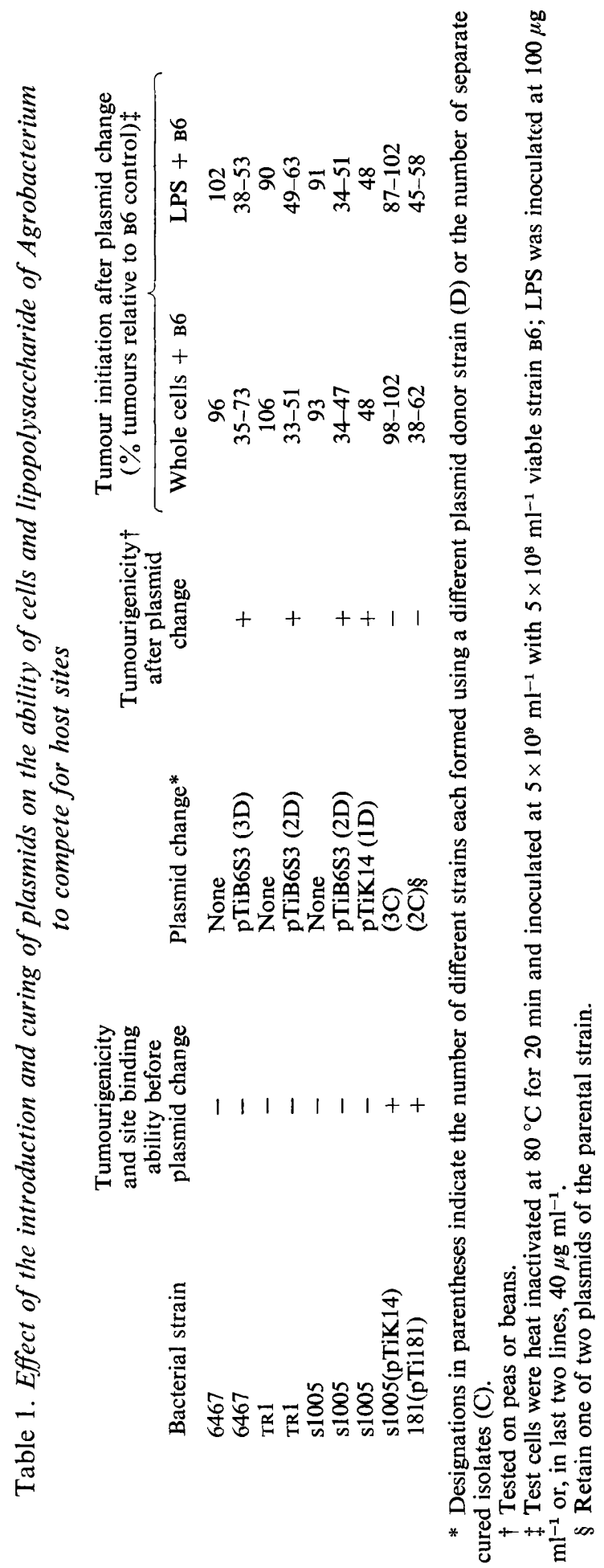


of the plasmid (Whatley et al., 1976) and three additional plasmid-cured strains (c58c9, $\mathrm{ACH} 5 \mathrm{C} 3$ and $\mathrm{B} 91 \mathrm{Q} 5)$ also retained site binding activity (data not shown). Similarly, $A$. radiobacter strain ATCC 4718 showed site binding ability (Lippincott \& Lippincott, 1969) but does not contain a plasmid (Zaenen et al., 1974).

We conclude that the ability of agrobacteria to adhere to host sites may be determined by either chromosomal or plasmid genes which affect LPS structure. Because the structural features of LPS essential for adherence are unknown and the degree of variation consistent with adherence is unknown, the effect of the plasmid and chromosomal determinants may or may not be identical, although they could have equal relevance to the infection process. It seems probable that most virulent agrobacteria have both chromosomal and plasmid genes which can determine adherence, since both the $\mathrm{K} 14$ and $\mathrm{B} 6 \mathrm{~s} 3$ virulence plasmids confer site binding ability on non-site binding recipient strains and since four 'naturally' virulent strains (C58, $\mathrm{ACH} 5, \mathrm{~B} 91$ and 181) when cured of their virulence plasmid retain site binding activity, as does avirulent plasmid-free strain ATCC 4718. Determination of the structure of LPS which is essential for adherence in different strains of agrobacteria and the discovery of means to cure additional strains of their plasmids will resolve these relationships.

These investigations were supported in part by Public Health Service research grant AI12149 from the National Institute for Allergy and Infectious Diseases and by a grant (no. 10316) from the 'Fonds voor Kollektief Fundamenteel Onderzoek'. We thank Peggy Bustamante for excellent technical assistance in these studies.

\section{REFERENCES}

Bomhoff, G., KLAPwiJK, P. M., Kester, H. C. M., Schilperoort, R. A., Hernalsteens, J. P. \& SCHELl, J. (1976). Octopine and nopaline synthesis and breakdown genetically controlled by a plasmid of Agrobacterium tumefaciens. Molecular and General Genetics 145, 177-181.

CURrier, T. C. \& Nester, E. W. (1976a). Isolation of covalently closed circular DNA of high molecular weight from bacteria. Analytical Biochemistry 76, 431-441.

Currier, T. C. \& Nester, E. W. (1976b). Evidence for diverse types of large plasmids in tumorinducing strains of Agrobacterium. Journal of Bacteriology 126, 157-165.

Engler, G., Holsters, M., Van Montagu, M., SChell, J., Hernalsteens, J. P. \& Schilperoort, R. (1975). Agrocin 84 sensitivity: a plasmid determined property in Agrobacterium tumefaciens. Molecular and General Genetics 138, 345-349.

Genetello, C., Van Larebeke, N., Holsters, M., De Picker, A., Van Montagu, M. \& Schell, J. (1977). Ti plasmids of Agrobacterium as conjugative plasmids. Nature, London 265, 561563.

KeRR, A. \& HTAY, K. (1974). Biological control of crown gall through bacteriocin production. Physiological Plant Pathology 4, 37-44.

KerR, A. \& Roberts, W. P. (1976). Agrobacterium: correlations between and transfer of pathogenicity, octopine and nopaline metabolism and bacteriocin 84 sensitivity. Physiological Plant Pathology 9, 205-211.

LipPincotT, B. B. \& LippincotT, J. A. (1969). Bacterial attachment to a specific wound site as an essential stage in tumor initiation by Agrobacterium tumefaciens. Journal of Bacteriology 97 , $620-628$.
LippincotT, J. A. \& Heberlein, G. T. (1965). The quantitative determination of the infectivity of Agrobacterium tumefaciens. American Journal of Botany 52, 856-863.

LIPPINCOTT, J. A., BEIDERBECK, R. \& LIPPINCOTT, B. B. (1973). Utilization of octopine and nopaline by Agrobacterium. Journal of Bacteriology 116, 378-383.

Petit, A. \& Tourneur, J. (1972). Perte de virulence associée à la perte d'une activité enzymatique chez Agrobacterium tumefaciens. Comptes rendus hebdomadaire des séances de l'Académie des sciences, Series D 275, 137-139.

Van Larebeke, N., Genetello, C., Schell, J., Schilperoort, R. A., Hermans, A. K., HeRnalsteens, J. P. \& Van Montagu, M. (1975). Acquisition of tumour-inducing ability by nononcogenic agrobacteria as a result of plasmid transfer. Nature, London 255, 742-743.

Watson, B., Currier, T. C., Gordon, M. P., Chilton, M.-D. \& Nester, E. W. (1975). Plasmid required for virulence of Agrobacterium tumefaciens. Journal of Bacteriology 123, 255-264.

WestPhal, O. \& JANN, K. (1965). Bacterial lipopolysaccharides. Extraction with phenol-water and further application of the procedure. Methods in Carbohydrate Chemistry 5, 83-91.

Whatley, M. H., Bodwin, J. S., Lippincott, B. B. \& LippincotT, J. A. (1976). Role for Agrobacterium cell envelope lipopolysaccharide in infection site attachment. Infection and Immunity 13, 1080-1083.

Zaenen, I., Van Larebeke, N., Teuchy, H., Van Montagu, M. \& Schell, J. (1974). Supercoiled circular DNA in crown-gall inducing Agrobacterium strains. Journal of Molecular Biology 86, 109-127. 